\title{
PEMBELAJARAN MATERI PENDIDIKAN AGAMA ISLAM (PAI) BERWAWASAN MODERAT
}

\author{
Muchlis \\ Sekolah Tinggi Keguruan dan Ilmu Pendidikan (STKIP) Bima \\ E-Mail: muchlisdarwis06@gmail.com
}

\begin{abstract}
Abstrak: Pada beberapa institusi pendidikan sering tidak disadari telah melahirkan peserta didik / siswa yang memiliki sikap menutup diri dari kebenaran yang disampaikan oleh pihak lain, kecenderungan kepada pemahaman dan sikap ekstrim. Konsep Pendidikan Agama Islam (PAI) berwawasan moderat hadir untuk mengatasi hal tersebut. Sehingga dalam memahami nilai-nilai pokok multikultural mulai dari sikap inklusif terhadap perbedaan-perbedaan, menghormati, demokrasi, toleransi, menghargai hasil karya orang lain, sikap mengutamakan persatuan dan kesatuan dalam suatu komunitas atau masyarakat yang berbeda latar belakang suku, budaya, bahasa, agama, dan lain-lain, sehingga pada akhirnya siswa diharapkan mampu mempraktekkan sikap-sikap tersebut dalam kehidupan sehari-hari. Metode pembelajaran Pendidikan Agama Islam (PAI) berwawasan moderat yang dimaksud dalam tulisan ini adalah terfokuskan pada tiga hal; yaitu strategi pengorganisasian pembelajaran, strategi penyampaian pembelajaran, dan strategi pengelolaan pembelajaran.
\end{abstract}

Kata Kunci: Pembelajaran PAI, moderat.

\section{PENDAHULUAN}

Allah Subhanahu wa Ta'ala telah mengokohkan posisi Umat Islam sebagai ummatan wasathan ${ }^{1}$ (umat pertengahan), moderat dan menjadi teladan bagi umat yang lain. Posisi pertengahan ini diibaratkan seperti posisi Ka'bah yang berada pada pertengahan dataran bumi ${ }^{2}$.

Moderat adalah posisi yang menjadikan manusia tidak memihak ke kiri dan ke kanan, sehingga mengantarkan manusia berlaku adil. Moderat juga bermakna pertengahan dalam pandangan tentang Tuhan dan dunia, meraih dunia dan akhirat, meraih materi yang bersifat duniawi tetapi dengan nilai-nilai samawi ${ }^{3}$.

Dalam konteks pendidikan Agama Islam konsep moderat ini berdasarkan

1 QS al-Baqarah: 143

2 https://www.republika.co.id/berita/dunia-islam/ islam-nusantara/16/05/26/o7s4s3394-kabah-ternyataterletak-tepat-di-pusat-bumi. Diakses pada 15 Februari 2020.

3 M. Quraish Shihab, Tafsir Al-Mishbah: Pesan, Kesan dan Keserasian Al-Qura'an, Volume I, (Jakarta: Lentera Hati, 2002), 347-348. kenyataan bahwa manusia cenderung memihak kepada salah satu diantara dua pilihan, atau untuk mengikis sikap ekstremisme baik ke kiri maupun ke kanan, memunculkan persaudaraan, toleransi, perdamaian dan Islam sebagai rahmatan lil 'alamin.

Pendidikan Islam merupakan suatu upaya untuk mentransfer nilai-nilai dan ajaran Islam dari orang tua/pendidik kepada anak didik agar anak dapat mempunyai pengetahuan, pemahaman dan pengamalan ajaran Islam yang utuh dan benar.

Pendidikan agama Islam salah satunya berfungsi sebagai wahana untuk memahami Islam secara kaffah, artinya PAI tidak boleh hanya berfokus pada peningkatan kemampuan ritual dan keyakinan tauhid semata, melainkan juga meningkatkan akhlak sosial kemanusiaan serta mampu menumbuhkan daya kritis dan kreatif. Oleh sebab itu realitas keragaman tersebut merupakan 
tantangan bagi Pendidikan Agama Islam (PAI) untuk mengembangkan pembelajaran yang mampu menjadikan peserta didik sebagai manusia yang mampu mengontrol diri agar tidak memiliki pemikiran dan menampilkan sikap ekstrim dalam kaitannya menjalin hubungan dengan orang lain.

Salah satu upaya tindakan preventif dalam mengembangkan kesadaran dan pemahaman masyarakat akan pentingnya sikap moderat, menjunjung tinggi nilai keadilan, serta keteladanan adalah dengan penerapan pembelajaran materi Pendidikan Agama Islam (PAI) berwawasan moderat. Jika sudah terlanjur terjadi perilaku ekstrim, langkah yang harus dilakukan adalah memberikan mengadakan interaksi sosial, berdialog, dan terbuka dengan semua pihak yang mempunyai latar belakang agama, budaya, ras, bahasa dan peradaban yang berbeda.

Pembelajaran materi Pendidikan Agama Islam (PAI) berwawasan moderat adalah pembelajaran yang berusaha mengembangkan kompetensi anak dalam rangka menerima perbedaan-perbedaan yang ada pada manusia. Sehingga siswa mampu belajar hidup dalam perbedaan, membangun saling percaya diantara masyarakat multikultural, memelihara saling pengertian, menjunjung sikap saling menghargai terbuka dalam berpikir, apresiasi dan interdependensi, menyelesaikan konflik dan rekonsiliasi tanpa kekerasan. ${ }^{4}$

\section{METODE PENELITIAN}

Dalam penulisan artikel ini menggunakan metode penelitian jenis perbandingan literatur yang berasal dari sumber primer seperti artikel jurnal, kajian fenomenologi yang terkait dengan isu-isu terhangat dalam dunia pendidikan agama

$4 \quad$ Muthoifin, Pemikiran Pendidikan Multikultural Ki Hadjar Dewantara, dalam Jurnal Intizar, Vol. 21, No. 2, 2015, hlm. 299.
Islam. Selain itu juga membandingkan dengan teori-teori tentang PAI terdahulu dan dibandingkan dengan masa sekarang.

\section{HASIL PENELITIAN}

Penjelasan al-Quran tentang moderat, umumnya menggunakan istilah 'al-Wasathiyyah'. Walaupun sebenarnya terdapat perbedaan-perbedaan dengan pemahaman moderat dalam konteks saat ini. Oleh sebab itu pemahaman dasar ini bisa dijadikan akar dalam memahami moderatisme Islam yang sebenarnya.

Kata wasath (طََّ) berarti 'posisi menengah diantara dua posisi yang berlawanan'. Kata wasath (طَسَ) dalam berbagai bentuknya dalam Al-Qur'an disebut lima kali, masing-masing dalam QS. al-Baqarah [2]: 143 dan 238, QS. alMa'idah [5]: 89, QS. al-Qalam [68]:28, serta QS. al-'Adiyat [100]: 5. Pada dasarnya penggunaan istilah wasath dalam ayatayat tersebut dapat merujuk kepada pengertian tengah, adil, dan pilihan 5 .

Raghib al-Ashfahani mengartikannya sebagai pertengahan antara sikap الإفراط (melebihi batas) dan التفريط (sembrono/ melalaikan), sehingga digolongkan sikap terpuji seperti العواء (setara), العدل /النصفة (keadilan) 6 .

Muchlis M. Hanafi mendefinisikan moderat (al-wasath) sebagai metode berpikir, berinteraksi dan berperilaku secara tawazun (seimbang) dalam menyikapi dua keadaan, sehingga ditemukan sikap yang sesuai dengan prinsip-prinsip Islam dan tradisi masyarakat, yaitu seimbang dalam akidah, ibadah dan akhlak ${ }^{7}$. Beberapa

5 M. Quraish Shihab, dkk., Ensiklopedia AlQur'an: Kajian Kosakata, Jilid III, (Jakarta: Lentera Hati, 2007), 1070-1071.

6 ar-Ragib al-Ashfahani, Kamus al-Qur'an: Jilid 3 (terjemah: Ahmad Zaini Dahlan), (Depok: Pustaka Khazanah Fawaid, 2017), 766.

7 Muchlis M. Hanafi, Moderasi Islam: Menangkal Radikalisasi Berbasis Agama, (Jakarta: Ikatan Alumni al-Azhar dan Pusat Studi al-Qur'an, 2013), 3-4. 
ciri Islam moderat yaitu tawassuth (mengambil jalan tengah), tawazun (berkeseimbangan), i'tidâl (lurus dan tegas), tasamuh (toleransi), musawah (egaliter), syura (musyawarah), ishlah (reformasi), aulawiyah (mendahulukan yang prioritas), tathawwur wa ibtikar (dinamis dan inovatif) $^{8}$.

\section{Signifikansi PAI Berwawasan Moderat di Sekolah}

Signifikansi wawasan moderat diajarkan melalui pendidikan agama Islam, diantaranya berlandaskan pada argumen berikut; Pertama, menghilangkan التفريط الإفراط (melebihi batas) dan (sembrono/melalaikan). Moderasi beragama dapat diartikan dengan mencari jalan tengah, dari masing-masing pemeluk agama yang tidak ekstrim dengan sudut pandangnya, dalam berbagai permasalahan yang terkait dengan agama atau dunia. Moderat adalah sikap untuk meminimalisir kelompok yang ekstrim dalam beragama (al-ghuluw fi ad-din), juga kelompok yang mengabaikan ketentuanketentuan agama.

Kedua, moderat berkaitan erat dengan toleransi. Toleransi merupakan sikap memberi ruang dan tidak mengganggu hak orang lain untuk berkeyakinan, mengekspresikan keyakinannya, dan menyampaikan pendapat, meskipun hal tersebut berbeda dengan apa yang kita yakini. Toleransi mengacu kepada sikap terbuka, lapang dada, sukarela, dan lembut dalam menerima perbedaan. Toleransi selalu disertai dengan sikap hormat, menerima orang yang berbeda sebagai bagian dari diri kita, dan berpikir positif 9 .

8 Afrizal Nur dan Mukhlis Lubis, "Konsep Wasathiyah Dalam Al-Quran; (Studi Komparatif Antara Tafsir Al-Tahrir Wa At-Tanwir dan Aisar At-Tafasir", Jurnal An-Nur, Vol. 4 No. 2, 2015, hal. 212-213.

9 Badan Litbang dan Diklat Kementrian Agama RI, Moderasi Beragama, Cet. I, (Jakarta: Kementrian Agama RI, 2019), 43-44
Ketiga, sikap moderat dapat menghadirkan keadilan dan keseimbangan dalam kehidupan. Salah satu prinsip dasar dalam moderasi beragama adalah selalu menjaga keseimbangan antara dua hal, misalnya keseimbangan antara akal dan wahyu, antara jasmani dan rohani, antara hak dan kewajiban, antara kepentingan individual dan kemaslahatan komunal, antara keharusan dan kesukarelaan, antara teks agama dan ijtihad tokoh agama, antara gagasan ideal dan kenyataan, serta keseimbangan antara masa lalu dan masa depan. Dengan demikian, inti dari moderasi adalah adil dan berimbang dalam memandang, menyikapi, dan mempraktikkan semua konsep yang berpasangan sebelumnya. Keadilan dan keseimbangan akan lebih mudah terbentuk jika seseorang memiliki tiga karakter utama dalam dirinya, yaitu: kebijaksanaan (wisdom), ketulusan (purity), dan keberanian (courage) ${ }^{10}$.

\section{Implementasi Pembelajaran Pendidikan Agama Islam (PAI) Berwawasan Moderat}

Materi tentang pendidikan agama Islam haruslah mengandung nilai-nilai dan ajaran-ajaran dari agama Islam itu sendiri. Untuk itu, ketika menyusun materi dalam mata pelajaran pendidikan agama Islam hendaknya memasukkan nilai-nilai keislaman di dalamnya, di antaranya adalah wawasan moderat. Sehingga ketika peserta didik tersebut dapat memahami ajaran agamanya dengan baik dan berinteraksi dengan orang lain dia dapat mengaplikasikan pengetahuannya sesuai dengan nilai-nilai dari ajaran agama Islam. ${ }^{11}$.

10 Badan Litbang dan Diklat Kementrian Agama RI, ...., 19-20.

11 Fahruozi dan Muthoifn, Nilai-Nilai Pendidikan Tauhid dalam Kisah Ashabul Ukhdud Surat Al-Buruj Perspektif Ibn Katsir dan Hamka, Jurnal Profetika, Jurnal Studi Islam, Vol. 19, No. 2, Desember 2018 
Penyusunan materi tentang pendidikan agama Islam yang mencakup pendidikan tauhid, fikih, akhlak, muamalah, dan lain sebagainya seharusnya dapat mengantarkan peserta didiknya menjadi manusia yang memahami ajaran agamanya dengan baik dan komprehensif serta mampu mengaplikasikan dalam kehidupan sehari-hari dengan baik dan tepat sasaran.

Nilai-nilai moderat dapat diterapkan dalam setiap bidang ilmu agama Islam, sehingga dapat menggambarkan bahwa Islam itu adalah agama yang komprehensif dan dapat diterapkan dalam setiap waktu dan tempat (shalih li kulli zaman wa makan). Moderat dalam tauhid mencakup pemahaman dan praktik bahwa agama yang dianutnya adalah benar, tetapi disaat yang bersamaan tidak memusuhi orang yang memeluk agama yang lain yang berbeda dengan yang diyakininya. Moderat dalam fikih, mencakup pemahaman dan praktik bahwa ibadah itu suatu kewajiban, tetapi disaat yang bersamaanjuga memahami bahwa bekerja itu adalah sebuah keharusan. Moderat dalam akhlak, mencakup pemahaman dan praktik bahwa kebaikan itu ruang lingkupnya tidak terbatas, mencakup akhlak kepada Tuhan, manusia, dan alam sekaligus. Moderat dalam muamalah, mencakup pemahaman dan praktik bahwa transaksi keduniawiaan itu dapat berlangsung dengan siapa pun tanpa harus dibatasi oleh sekat agama dan selama membawa membawa kebaikan (maslahah) bagi diri sendiri dan orang lain.

Setidaknya, ada empat komponen yang harus diperhatikan dalam pengimpelementasian, yaitu: pertama, tujuan pembelajaran; kedua, materi atau bahan ajar; ketiga, metode mengajar; keempat, evaluasi pembelajaran. Semua komponen ini harus dipertimbangkan dalam merumuskan model kurikulum yang tepat dan penyediaan saran prasarana yang mendukung. Harapannya setelah siswa menerima pelajaran pendidikan agama Islam, siswa mengalami perubahan, seperti menjadi lebih moderat.

\section{Karakteristik Materi Pendidikan Agama Islam (PAI) Berwawasan Moderat}

Pendidikan agama adalah pendidikan yang memberikan pengetahuan dan membentuk sikap, kepribadian, dan keterampilan peserta didik dalam mengamalkan ajaran agamanya, yang dilaksanakan sekurang-kurangnya melalui mata pelajaran / kuliah pada semua jalur, jenjang, dan jenis pendidikan. Sedangkan fungsi dari pendidikan agama adalah membentuk manusia Indonesia yang beriman dan bertakwa kepada Tuhan Yang Maha Esa serta berakhlak mulia dan mampu menjaga kedamaian dan kerukunan hubungan interumat beragama maupun antarumat beragama. Adapun tujuan yang akan dicapai dalam pendidikan agama adalah untuk berkembangnya kemampuan peserta didik dalam memahami, menghayati, dan mengamalkan nilai-nilai ajaran agama yang diserasikan dengan penguasaannya dalam ilmu pengetahuan, teknologi dan seni.

Dalam konteks agama Islam, pendidikan agama Islam adalah sebagai salah satu wahana untuk memahami Islam secara kaffah, artinya Pendidikan Agama Islam (PAI) tidak boleh hanya berfokus pada peningkatan kemampuan ritual dan keyakinan tauhid semata, melainkan juga meningkatkan akhlak sosial kemanusiaan serta mampu menumbuhkan daya kritis dan kreatif. Oleh sebab itu realitas keragaman yang ada pada masyarakat merupakan tantangan bagi Pendidikan Agama Islam (PAI) untuk mengembangkan pembelajaran Pendidikan Agama Islam (PAI) yang berwawasan moderat. Hal ini dituntut untuk merefleksikan, termasuk jika perlu mereformasi semua atau 
sebagian komponen kurikulum yang sebelumnya cenderung eksklusif menjadi kurikulum yang inklusif sehingga fungsi dari pendidikan agama tersebut bisa tercapai.

Salah satu argumen penting hadirnya moderasi beragama, khususnya di Indonesia, adalah fakta masyarakat Indonesia yang sangat plural dan multikultural. Bangsa kita terdiri dari beragam suku, etnis, agama, bahasa, dan budaya. Hukum alamnya, keragaman meniscayakan adanya perbedaan, dan setiap perbedaan potensial melahirkan gesekan atau konflik yang dapat menimbulkan ketidakseimbangan ${ }^{12}$.

Menurut Cecelia Lynch sebagaimana dikutip oleh Muhammad Ali, paling tidak ada lima kategori sikap beragama seseorang atau kelompok yang berimplikasi pada sikap kulturalnya, yaitu: pertama, eksklusif; yaitu sikap mengagungkan superioritas sistem kepercayaan sendiri dan menonjolkan hak untuk menyebarkan sistem itu seluas mungkin. Kedua, inklusif; yaitu sikap menerima validitas atau hak sistem kepercayaan-kepercaaa lainnya untuk eksis, meskipun sistem kepercayaan lain itu dianggap kurang sempurna atau kurang benar. Ketiga, pluralis; yaitu mengakui bahwa kebenaran itu beragam dan bersikap positif akan kesamaan tujuan dan fungsi semua agama. Keempat, apologetik; yaitu dalam arti sikap mempertahankan doktrin ketika ditantang dari luar maupun dalam arti usaha untuk menunjukkan bahwa doktrin sendiri konsisten dan superior dibanding doktrin-doktrin lain. Kelima, sinkretik; yaitu mengakui beragamnya tradisi keagamaan yang ada tidak hanya di dalam masyarakat yang multibudaya, tetapi di dalam pribadi ${ }^{13}$.

12 Badan Litbang dan Diklat Kementrian Agama RI, ..., 54-55.

13 Muhammad Ali, Teologi Pluralis Multikultural, Menghargai Kemajemujan, Menjalin Kebersamaan, cet. I, (Jakarta: Penerbit Buku Kompas, 2003), 72-75.
Pendidikan Agama Islam (PAI) berwawasan moderat ini penting untuk diberikan kepada anak didik mulai level sekolah dasar, menengah, sampai perguruan tinggi. Hal ini lebih disebabkan karena kondisi peserta didik pada masamasa tersebut masih sangat labil. Artinya dengan diberikan pendidikan agama Islam berwawasan moderat diharapkan pemahaman mereka dalam menyikapi perbedaan-perbedaan yang ada dalam masyarakat sehingga bisa mapan dan lebih toleran, dan menghargai perbedaan.

Wawasan moderat hadir untuk menciptakan keseimbangan dalam kehidupan. Sebuah keseimbangan sangat diperlukan karena secara alamiah Tuhan telah menciptakan segala sesuatu yang berada di dunia ini secara berpasangan. Moderat adalah upaya agar dalam praktik kehidupan, manusia tidak terjebak pada salah satu sisi pasangan yang diciptakan.

Materi PAI berwawasan moderat adalah sebuah usaha bagaimana Pendidikan Agama Islam (PAI) mampu mengembangkan kompetensi anak didik dalam rangka menerima perbedaan-perbedaan yang ada pada manusia, Sehingga siswa mampu belajar hidup dalam perbedaan, membangun saling percaya (mutual trust) diantara masyarakat multikultural, memelihara saling pengertian (mutual understanding), menjunjung sikap saling menghargai (mutual respect), terbuka dalam berpikir, apresiasi dan interdependensi, menyelesaikan konflik dan rekonsiliasi tanpa kekerasan dengan berlandaskan nilai-nilai ketuhanan.

Dapat dikatakan juga materi

Pendidikan Agama Islam (PAI) berwawasan moderat berusaha membentuk manusia yang sempurna (insan kamil), dimana peserta didik tidak hanya dibentuk untuk menjadi manusia yang saleh secara individual, tapi juga dididik dan dibimbing untuk menjadi manusia yang saleh secara sosial, manusia 
yang mampu hidup berdampingan, berinteraksi dengan seluruh komunitas yang berbeda latar belakang, baik suku, ras, budaya dan lain-lain dalam rangka membentuk masyarakat yang damai, adil, dan makmur.

Dari sini bisa dikatakan materi Pendidikan Agama Islam (PAI) berwawasan moderat berusaha untuk memberi kesempatan yang sama kepada setiap anggota masyarakat untuk mendapatkan hak-haknya sebagai manusia yang merdeka, seperti hak untuk mengeluarkan pendapat, hak untuk mengembangkan kreatifitasnya secara maksimal, hak untuk mendapatkan pendidikan, hak untuk mendapatkan perlakuan yang sama (persamaan), serta hak untuk mendapatkan keadilan.

Meskipun demikian ada beberapa yang perlu dipertegas dari Materi Pendidikan Agama Islam (PAI) berwawasan moderat, yaitu:

a. Dalam menyikapi hubungan antar agama, paradigma materi Pendidikan Agama Islam (PAI) berwawasan moderat adalah "bersifat pertengahan (wasathiyyah)" hal ini perlu dipertegas karena ada manusia yang condong kepada sesuatu secara berlebihan (ifrath), juga terlalu memudahkan di sisi yang lain (tafrith).

b. Kaitannya dengan perbedaan yang terjadi, bahwa paradigma materi Pendidikan Agama Islam (PAI) berwawasan moderat adalah mengakui dan menerima keberagaman yang ada dengan penuh kesadaran bahwa perbedaan tidak harus disikapi dengan perselisihan tapi harus dipahami bahwa kita harus menerimanya dengan penuh lapang dada (moderat), dan dengan keyakinan bahwa moderat itu pilihan terbaik, adil, dan utama yang akan mendatangkan keseimbangan, keadilan, dan kemuliaan. Dengan kata lain bahwa dalam per- spektif pendidikan agama Islam terkait keragaman yang ada harus dikembangkan sesuai dengan etika yang diatur dalam agama Islam, sehingga mesti ditananamkan kecintaan peserta didik terhadap keragaman itu sendiri sesuai dengan ajaran islam. Termasuk umat Islam tidak boleh memaksakan keyakinan yang dipeluknya kepada pemeluk orang lain yang berbeda dengan keyakinan yang dipilihnya.

\section{Karakteristik Pembelajaran Materi Pendidikan Agama Islam (PAI) Berwawasan Moderat \\ Metode pembelajaran dapat} diklasifikasikan menjadi: (1) Strategi pengorganisasian isi pembelajaran, (2) strategi penyampaian isi pembelajaran, dan (3) strategi pengelolaan pembelajaran ${ }^{14}$.

Dalam kaitannya dengan pembelajaran materi Pendidikan Agama Islam (PAI) berwawasan moderat, strategi pengorganisasian adalah suatu metode untuk mengorganisasi isi bidang studi Pendidikan Agama Islam (PAI) yang dipilih untuk pembelajaran. Pengorganisasian isi bidang studi mengacu pada kegiatan pemilihan isi, penataan isi, pembuatan diagram, skema, format penyampaian materi yang cocok dengan siswa.

Strategi penyampaian pembelajaran materi Pendidikan Agama Islam (PAI) berwawasan moderat adalah metodemetode penyampaian pembelajaran materi Pendidikan Agama Islam (PAI) yang dikembangkan untuk membuat siswa dapat merespon dan menerima pelajaran Pendidikan Agama Islam (PAI) berwawasan moderat dengan mudah, cepat, dan menyenangkan. Karena itu,

14 Mashudi, Pengelolaan, Penyampaian, dan Pengorganisasian Isi Pembelajaran dalam Variabel Pembelajaran, Jurnal Al-'Adalah, Volume IX Edisi 26 Nomor 2 April-Agustus 2006, 107. 
penetapan strategi penyampaian perlu menerima serta merespons masukan dari peserta didik.

Mengenai strategi penyampaian, secara umum seorang guru agama harus berusaha mengubah paradigma mengajarnya, yang asalnya teacher oriented (pembelajaran berpusat dari guru) menuju kepada student oriented (pembelajaran yang berpusat dari siswa) atau dalam bahasa lain pembelajaran PAI harus berubah dari teaching menjadi learning. Dalam kaitan pembelajaran materi PAI berwawasan moderat, seorang guru harus memberi kesempatan kepada siswa untuk mengekplorasi dan mengelaborasi suatu materi yang disampaikan. Misalnya ketika belajar tentang materi toleransi, seorang guru memberi kebebasan kepada peserta didik untuk mencari kasus-kasus yang terjadi di lingkungannya terkait dengan materi toleransi ini.

Disisi lain seorang guru juga harus kaya dengan metode-metode pembelajaran, karena metode yang baik dalam sebuah pembelajaran idealnya bervariatif, baik antara teknik yang berpusat pada guru dengan teknik-teknik yang melibatkan anak didik. Adapun metode yang bisa diterapkan untuk menanamkan keimanan dan ketakwaan serta akhlakul karimah sebagaimana yang dijelaskan oleh Abdurahman alNahlawi ${ }^{15}$ adalah sebagai berikut:

a. Metode dialog Qur'ani dan Nabawi

b. Mendidik melalui kisah-kisah Qur'ani dan Nabawi

c. Mendidik melalui perumpamaan (amtsal) Qur;ani dan Nabawi

d. Mendidik melalui ketaladanan

e. Mendidik melalui aplikasi dan pengamalan

f. Mendidik melalui Ibrah dan nasehat; dan

15 Abdurrahman An-Nahlawi, Pendidikan Islam di Rumah, Sekolah dan Masyarakat, (Jakarta: Gema Insani, 1995), 204. g. Mendidik melalui targhib (membuat senang) dan Tarhib (membuat takut).

Andang mengemukakan sepuluh metode yang dapat digunakan dalam proses mengajar, yaitu: metode ceramah, tanya jawab, diskusi, demonstrasi, penugasan (resitasi), pemecahan masalah (problem solving), bercerita, proyek, karya wisata, dan debat ${ }^{16}$.

Maka salah satu strategi yang cocok dalam pembelajaran materi PAI berwawasan moderat adalah strategi pembelajaran kooperatif (cooperative teaching strategies), karena strategi diyakini akan mampu menumbuhkan semangat kebersamaan dan etos kerja sama diantara para siswa. Sebuah proses pembelajaran dikatakan menggunakan cooperative learning jika bercirikan lima unsur ${ }^{17}$, yaitu: (1) Saling ketergantungan positif (positive interdependence); Interaksi langsung / tatap muka yang membangun (face-to- face promotive interaction); (3) Pertanggunjawaban secara individual (Individual accountability); (4) ketrampilan sosial (social skill); (5) proses kelompok (groups process).

Dapat dilihat bahwa dengan menggunakan strategi cooperative learning siswa dibiasakan untuk belajar berdemokrasi, bekerjasama dengan temannya, saling menghormati dan menghargai prinsip-prinsip kawan, saling memahami dan saling mendukung kepada suatu kemajuan. Dengan membiasakan peserta didik dengan nuansa-nunasa spirit moderat dalam proses pembelajaran seperti ini, peserta didik diharapkan terbiasa juga untuk mengimplementasikan nilai-nilai moderat tersebut dalam kehidupan bermasyarakat.

Metode lain yang cocok dengan pembelajaran materi PAI berwawasan

\footnotetext{
16 Andang, dkk., Strategi Pembelajaran, (Yogyakarta: Deepublish, 2017), 119-130.

17 Andang, dkk. ..., 89-90.
} 
moderat adalah metode dialog, hal ini disebabkan kajiannya yang cenderung membandingkan masalah pemahaman dan keyakinan yang berbeda. Metode dialog ini akan membiasakan anak didik untuk melahirkan suasana dan hubungan yang dialogis terutama dalam konteks memahami dan menghargai keanekaragaman suku, ras, budaya, bahasa, dan agama. Diharapkan dengan metode ini akan menjadikan anak didik mempunyai sikap saling mengenal dan memahami antar keyakinan dan agama yang berbeda tersebut.

Akhirnya seorang guru harus cerdas dan teliti dalam memilih metodemetode yang akan digunakan dalam pembelajaran, seorang guru harus mampu memilih metode yang sesuai dengan materi PAI berwawasan moderat yang sedang dipelajari dan kondisi peserta didik. Pada prinsipnya tidak ada metode yang jelek selama metode tersebut sesuai dengan materi, kondisi siswa, sarana prasarana dan biaya yang dimiliki suatu lembaga pendidikan.

Media pembelajaran adalah alat bantu apa saja yang dapat dijadikan sebagai penyalur pesan guna mencapai tujuan pembelajaran ${ }^{18}$. Secara umum penggunaan media harus memperhatikan karakteristik peserta didik dan materi yang disampaikan, sehingga akan menimbulkan interaksi pembelajaran yang komunikatif antara guru dan peserta didik . Media pembelajaran sangat membantu peserta didik dalam memahami suatu materi, contoh ketika seorang guru menjelaskan tentang materi "pentingnya toleransi" seorang guru bisa memutarkan film diantaranya adalah "Ayat-ayat Cinta 2", disitu peserta didik akan mengetahui tentang pentingnya saling menghormati, menghargai ras orang lain, menghargai perbedaan

18 Djamarah, dkk. Strategi Belajar Mengajar, (Jakarta: PT Rineka Cipta, 2006), 136. pendapat bahkan perbedaan keyakinan sekalipun.

Pemilihan media pembelajaran juga harus memperhatikan strategi pengelolaan pembelajaran karena strategi tersebut sebagai suatu metode untuk menata interaksi antara peserta didik dengan komponen-komponen metode pembelajaran lain, seperti pengorganisasian dan penyampaian isi pembelajaran.

\section{Hasil Pembelajaran Materi PAI Berwawasan Moderat}

Hasil pembelajaran dapat diklasifikasikan menjadi keefektifan (effectiveness), efisiensi (efficiency), dan daya tarik $^{19}$. Keefektifan pembelajaran dapat diukur dengan kriteria: (1) kecermatan penguasaan kemampuan atau perilaku yang dipelajari; (2) kecepatan unjuk kerja sebagai bentuk hasil belajar; (3) kesesuaian dengan prosedur kegiatan belajar yang harus ditempuh; (4) kuantitas unjuk kerja sebagai bentuk hasil belajar; (5) kualitas hasil akhir yang dapat dicapai; (6) tingkat alih belajar; (7) tingkat retensi belajar ${ }^{20}$.

$$
\text { Dalam konteks Pembelajaran }
$$

materi PAI berwawasan moderat hasil pembelajaran bisa diukur dari kemampuan siswa dalam memahami dan mengaplikasikan nilai-nilai moderat, diantaranya: mampu belajar hidup dalam perbedaan dengan seluruh siswa yang berbeda latar belakang budaya, suku, dan etnis, status sosial yang ada di sekolah dan di lingkungan masyarakat, membangun saling percaya (mutual trust) diantara siswa dan masyarakat multikultural, memelihara saling pengertian (mutual understanding) dengan siswa dan masyarakat multikultural,

19 Mieke O Mandagi, \& I Nyoman Sudana Degeng, Model dan Rancangan Pembelajaran, (Malang: CV. Seribu Bintang, 2019), 124.

20 Muhaimin, M. A., \& Ali, N., Paradigma Pendidikan Islam: Upaya Mengefektifkan Pendidikan Agama Islam di Sekolah. (Bandung: Rosdakarya, 2002), 156. 
menjunjung sikap saling menghargai (mutual respect) perbedaan pendapat dan keyakinan beragama, berpikir terbuka, menyelesaikan konflik dan rekonsiliasi tanpa kekerasan, seperti mampu menyelesaikan masalah disekolah dengan mengutamakan musyawarah yang dialogis diantara kawan sesama.

Dari pernyataan tersebut bisa dikatakan juga bahwa hasil pembelajaran materi PAI berwawasan moderat juga bisa dilihat dari motivasi peserta didik dalam mengembangkan nilai-nilai moderat dalam kehidupan sehari- hari di lingkungan sekolah maupun masyarakat, misalnya mengikuti kegiatan-kegiatan diskusi (termasuk lintas agama dan budaya), mengikuti secara aktif acaraacara pertunjukan lainnya.

\section{KESIMPULAN}

Dalam memahami nilai-nilai pokok moderat mulai darisikap inklusif terhadap perbedaan-perbedaan, menghormati, keadlilan, persamaan, kemuliaan, toleransi, menghargai hasil karya orang lain, sikap mengutamakan persatuan dan kesatuan dalam suatu komunitas atau masyarakat yang berbeda latar belakang suku, agama, budaya, status, bahasa, dan lain-lain. Sehingga pada akhirnya siswa diharapkan mampu mempraktekkan sikap-sikap tersebut dalam kehidupan sehari-hari. Metode pembelajaran yang dimaksud terdiri dari tiga hal, yaitu strategi pengorganisasian pembelajaran, strategi penyampaian pembelajaran, dan strategi pengelolaan pembelajaran materi PAI berwawasan moderat.

\section{DAFTAR PUSTAKA}

Ali, Muhammad. Teologi Pluralis Multikultural, Menghargai Kemajemujan, Menjalin Kebersamaan, cet. I. Jakarta: Penerbit Buku Kompas. 2003.

Al-Ashfahani, ar-Ragib. Kamus al-Qur'an: Jilid 3 (terjemah: Ahmad Zaini Dahlan). Depok: Pustaka Khazanah Fawaid. 2017.

An-Nahlawi, Abdurrahman. Pendidikan Islam di Rumah, Sekolah dan Masyarakat. Jakarta: Gema Insani. 1995.

Andang, dkk. Strategi Pembelajaran. Yogyakarta: Deepublish. 2017.

Badan Litbang dan Diklat Kementrian Agama RI. Moderasi Beragama. Cet. I. Jakarta: Kementrian Agama Ri. 2019.

Djamarah, Dkk. Strategi Belajar Mengajar. Jakarta: Pt Rineka Cipta. 2006.

Fahruozi dan Muthoifn, Nilai-Nilai Pendidikan Tauhid dalam Kisah Ashabul Ukhdud Surat Al-Buruj Perspektif Ibn Katsir dan Hamka, Jurnal Profetika, Jurnal Studi Islam, Vol. 19, No. 2, Desember 2018

Mashudi. Pengelolaan, Penyampaian, dan Pengorganisasian Isi Pembelajaran dalam Variabel Pembelajaran. Jurnal Al-'Adalah. Volume IX Edisi 26 Nomor 2 April-Agustus 2006.

M. Hanafi, Muchlis. Moderasi Islam: Menangkal Radikalisasi Berbasis Agama. Jakarta: Ikatan Alumni al-Azhar dan Pusat Studi al-Qur'an. 2013.

Muhaimin, M. A., \& Ali, N. Paradigma Pendidikan Islam: Upaya Mengefektifkan Pendidikan Agama Islam di Sekolah. Bandung: Rosdakarya. 2002.

Muthoifin. Pemikiran Pendidikan Multikultural Ki Hadjar Dewantara, dalam Jurnal Intizar, Vol. 21, No. 2: 299. 2015.

Nur, Afrizal dan Mukhlis Lubis, Konsep Wasathiyah dalam Al-Quran; (Studi Komparatif 
PROFETIKA, Jurnal Studi Islam, Vol.21, No. 1, Juni 2020: 11-20

Antara Tafsir Al-Tahrir Wa At-Tanwir dan Aisar At-Tafasir. Jurnal An-Nur, Vol. 4 No. 2, 2015.

O Mandagi, Mieke \& I Nyoman Sudana Degeng. Model dan Rancangan Pembelajaran. Malang: CV. Seribu Bintang. 2019.

Shihab, M. Quraish. Tafsir Al-Mishbah: Pesan, Kesan dan Keserasian Al-Qura'an. Volume 1. Jakarta: Lentera Hati. 2002.

Shihab, M. Quraish, dkk. Ensiklopedia Al-Qur'an: Kajian Kosakata, Jilid III. Jakarta: Lentera Hati. 2007.

https://www.republika.co.id/berita/dunia-islam/islam-nusantara/16/05/26/o7s4s3394kabah-ternyata-terletak-tepat-di-pusat-bumi. Diakses pada 15 Februari 2020. 